\title{
NEGLECTED PRRZE PROPERTY, TRACY ARM, JUNEAU MINING PRECINCT
}

\author{
By J. C. Roehm \\ Assoctate Engineer \\ 3942
}

The Neglected Prize is a copper-lead-zinc prospect located on Tracy Arm, one mile south of the first elbow. A blazed trayl leads up along the west side of the first creek past the point of the elbow to the east. The workings, which consist of several opencuts and a short shaft, are located along a high bench land which follows the east shore of the outer arm at an elevation of 800 feet. This prospect was discovered by Alex Butterbaugh in 1916. The greater portion of the cuts and the shaft were sunk following this discovery. In the years 1922 and 1923 the property was relocated by Eugene Owens and additional cuts extending the length of the vein were dug. Since then no work has been performed on the prospect.

The showing is contained in a belt of gneissic schist one-fourth mile in width and enclosed between a massive wide zone of diorite to the east and a narrow zone of diorite to the west. This zone strikes $N 25-35^{\circ} \mathrm{W}$, which conforms to the normal strike found along the west contact of the coast Batholith. The dip of the schistosity in the gneiss, and of the veins noted in the zone, are steeply to the west, which is contrary to the persistent east dip of the sediments and schist found along the west contact. This west dip may be explained by the overturning of the beds from a steep east dip to a steep west dip by continuous overlying pressure and weight. The gneissic schist is thinly banded and folded with considerable metamorphism evident. Metamorphic bands of phyllite are evident within the zone and due to their presence the writer is of the opinion the other schists are sedimentary, which are now aitered beyond recognition. Gneissic and banded structures ared prevalent throughout the zone. Paralieling the strike of the schistosity and the zone are mineralized zones which range in width from 10 to 50 feet. Three such zones were noted and the sulphide veins of this prospect occupy the central portion of one of the larger zones.

The high bench ridge along which this vein is situated is covered with timber and vegetal growth. The vein is exposed in eight cuts and at the collar of the shaft, reported to be 16 feet in depth, for a distance of 700 feet. The strike is $N 35^{\circ} \mathrm{W}$ and the dip is 
$80^{\circ} \mathrm{SW}$. Over the exposed length the vein matntatns an average width of 5 feet. Both walls are gnetssic schist with same shearing paralleling the strtke. Generally, the sulphides range from nearly massive near the center to lean disseminations into the walis. Along some of the shears near the center of the vein, which denotes a reopening of the vein, later sulphides consisting mainly of marcasite and some pyrite with mfnor amounts of sphalerite, gajena and chalcopyrlte, form massive bands. These range from seams to widths of 4 or 5 inches. The metallic sulphides noted in this ore are, in order of abundance: pyrite, pyrrhotite, marcasite, sphalerite, chalcopyrite and galena. Low gold and si3ver values were determined by assay. The gangue minerals consist mainiy of quartz, sericite, biotite, Ifmonite, and other unidentified minerals.

Samples 1084 to 1091 represent channel sampies from seven cuts and one at the collar of the shaft across the vein, ranging in width from 4 to 6 feet. These gave gold and silver values ranging from traces to $0.72 \mathrm{oz}$. per ton in gold and a trace to $1.60 \mathrm{oz}$. per ton of silver. Zinc ranges from 1.53 to 13.50 percent, averaging 5 to 6 percent. Copper ranged from 2.41 to 6.31 percent and averaged 3 percent.

Further prospecting and surface development is warranted on this prospect to extend the limits of the vein along the strike, followed by detail geological mapping. 